\title{
EFEKTIVITAS PERSYARATAN HYGIENE SANITASI TERHADAP USAHA RUMAH MAKAN DAN RESTORAN BERDASARKAN KEPMENKES RI NOMOR 1098/MENKES/ SK/VII $/ 2003^{1}$
}

\author{
Oleh \\ Gusti Ayu Dita Nomia Sari
}

Abstract

\begin{abstract}
Tourists who visited tourism destination in addition to the cultural and natural environment, food and drinks being the main attraction. Lack of awareness of the restaurant business to maintain cleanliness and sanitation are not uncommon cause of food poisoning. Legal issues raised in this study are: a) How obligation of entrepreneur restaurants and legal protection for consumers under the Consumer Protection Act; b) how the effectiveness of sanitation hygiene is based on Kepmenkes No. 1098 / Menkes / SK / VII / 2003 against the restaurants in the Ubud area. This study uses empirical legal research. The data is processed by analyzing qualitative descriptive analytical.
\end{abstract}

Keyword: Tourism, Restaurant, Hygiene sanitation, Food

\begin{abstract}
Abstrak
Wisatawan yang mengunjungi destinasi pariwisata selain budaya dan keindahan alam, makanan dan minuman menjadi daya tarik utama lainnya. Kurangnya kesadaran pengusaha restoran untuk menjaga kebersihan dan sanitasi yang tidak jarang menyebabkan terjadinya keracunan makanan. Isu hukum yang diangkat dalam penelitian ini adalah: a) Bagaimana kewajiban pelaku usaha rumah makan dan restoran dan perlindungan hukum bagi konsumen menurut UU Perlindungan Konsumen; b) bagaimana efektivitas hygiene sanitasi restoran berdasarkan Kepmenkes No. 1098 / Menkes / SK / VII / 2003 terhadap rumah makan dan restoran di kawasan ubud. Penelitian ini menggunakan penelitian hukum empiris. Data diolah dengan menganalisis deskriptif kualitatif analitis.
\end{abstract}

Kata kunci: Pariwisata, Rumah Makan \& Restoran, Makanan

Artikel ini merupakan karya ilmiah mahasiswa pada Program Studi Magister (S2) Ilmu Hukum Program Pascasarjana Universitas Udayana dan mengucapkan terimakasih kepada Prof. Dr. I Made Arya Utama, SH.M.Hum dan Dr. Putu Tuni Cakabawa Landra, SH. M.Hum selaku pembimbing tesis.

2 Mahasiswa Program Studi Magister (S2) Ilmu Hukum Universitas Udayana, Denpasar, Bali, Email: ditha.nomia@gmail.com 


\section{PENDAHULUAN}

Salah satu sektor andalan di Indonesia adalah pariwisata. Setiap pengeluaran dari wisatawan yang berkunjung merupakan sumber pendapatan bagi stakeholder yang bergerak dibidang usaha wisata termasuk pengusaha-pengusaha lokal. Beragam peluang usaha didapatkan pada sektor ini, diantaranya jasa transportasi, pemandu wisata, penyediaan jasa souvenir, penyediaan jasa makanan dan minuman dan lain sebagainya. $^{3}$

Undang-Undang Nomor 10 Tahun 2009 tentang Kepariwisataan (selanjutnya disingkat UU Kepariwisataan) Pasal 1 angka 3 memberikan pengertian pariwisata adalah berbagai macam kegiatan wisata dan didukung berbagai fasilitas serta layanan yang disediakan oleh masyarakat, pengusaha, pemerintah, dan pemerintah daerah. Berdasarkan pengertian tersebut kegiatan pariwisata memerlukan sinergi dari stakeholder pariwisata agar dapat menjadi pariwisata yang berkelanjutan. UU Kepariwisataan menyatakan usaha pariwisata meliputi daya tarik wisata; kawasan pariwisata; jasa transportasi pariwisata; jasa perjalanan wisata; jasa makanan dan minuman; penyediaan akomodasi; penyelenggaraan kegiatan hiburan dan rekreasi; penyelenggaraan pertemuan; perjalanan insentif; konferensi dan pameran; jasa informasi

\footnotetext{
I Gde Pitana \& I Ketut Surya Diarta, 2009, Pengantar Ilmu Pariwisata, CV Andi Offset, Yogyakarta, hlm. 186
}

pariwisata; jasa konsultan pariwisata; jasa pramuwisata; wisata tirta; dan spa. Untuk melayani keperluan wisatawan, maka disediakan berbagai fasilitas pokok pariwisata, fasilitas pelengkap, dan fasilitas penunjang pariwisata. Makanan dan minuman merupakan salah satu dari usaha pariwisata.

Makanan dan minuman adalah kebutuhan pokok bagi setiap orang yang memicu maraknya usaha rumah makan dan restoran terutama di destinasi pariwisata. Meningkatnya usaha rumah makan dan restoran tanpa diimbangi dengan perhatian terhadap kesehatan akan mempengaruhi citra destinasi wisata tersebut. Setiap usaha rumah makan dan restoran harus memenuhi persyaratan hygiene dan sanitasi makanan sesuai dengan Kepmenkes RI Nomor 1098/Menkes/ SK/VII/2003 tentang Hygiene dan Sanitasi Makanan, dalam Pasal 9 dinyatakan persyaratan hygiene dan sanitasi yaitu:
a. persyaratan lokasi dan bangunan;
b. persyaratan fasilitas sanitasi;
c. persyaratan dapur; ruang makan; dan gudang makanan;
d. persyaratan bahan makanan dan makanan jadi;
e. persyaratan pengolahan makanan;
f. persyaratan penyimpanan bahan makanan dan makanan jadi;
g. persyaratan penyajian makanan jadi;
h. persyaratan peralatan yang digunakan. 
Persyaratan-persyaratan tersebut harus dipenuhi oleh pelaku usaha yang akan bergerak dalam usaha makanan dan minuman atau restoran. Tetapi dalam prakteknya banyak rumah makan dan restoran tidak memenuhi persyaratan hygiene dan sanitasi. Bahkan terjadi kasus keracunan makanan oleh dua orang wisatawan Australia di kawasan Ubud yang menyebabkan kematian. ${ }^{4}$ Ubud dipilih sebagai objek penelitian sebab Ubud merupakan salah satu destinasi pariwisata. Dalam kasus tersebut tercermin adanya kesenjangan norma antara das seein dan das sollen.

Dari latar belakang diatas maka dapat dirumuskan permasalahan sebagai berikut:

1. Bagaimanakah?

2. Bagaimanakah efektivitas

Kepmenkes RI Nomor 1089/

M E N K E S / S K / V I I / 2003

terhadap usaha rumah makan dan restoran di kawasan Ubud?

Untuk menunjukkan originalitas dari jurnal ini, maka akan ditampilkan beberapa jurnal terdahulu sebagai pembanding. Pertama Peranan Hygiene dan Sanitasi Untuk Menjaga Kualitas Makanan dan Kepuasan Tamu di Hotel Inna Garuda Yogyakarta oleh Yuni Yuliastri dan Atun Yulianto. ${ }^{5}$

4 Available from: http://beritabali.com/ $\mathrm{red} / 2014 / 01 / 06 / 201401060004 /$ Ibu-danAnak-Warga-Asing-Tewas-Keracunan-diRestoran-Ubud.html

5 Yuni Yuliastri dan Atun Yulianto, Peranan Hygiene dan Sanitasi Untuk Menjaga Kualitas Makanan dan Kepuasan Tamu di Hotel Inna Garuda Yogyakarta, Jurnal Khasanah Ilmu,
Kedua HYGIENE DAN FASILITAS SANITASI RUMAH MAKAN DI WILAYAH KOTA GORONTALO oleh Ekawaty Prasetya. ${ }^{6}$ Perbedaan jurnal ini dan jurnal sebelumnya adalah jurnal ini membahas dan menganalisa tentang kewajiban pelaku usaha rumah makan dan restoran dan efektivitas Kepmenkes RI Nomor 1098/Menkes/ SK/VII/2003.

Secara garis besar dapat dikemukakan bahwa tujuan dari penelitian ini antara lain: ${ }^{7}$ Tujuan umum dari penelitian ini yaitu berupaya untuk melakukan pengembangan terhadap ilmu hukum serta dapat memberikan gambaran umum dari segi hukum, di bidang hukum kepariwisataan yang terfokus pada dimensi keamanan dalam kepariwisataan. Sedangkan Tujuan khusus penelitian karya ilmiah ini pertama untuk mengetahui dan memahami bagaimana kewajiban pelaku usaha rumah makan dan restoran serta perlindungan hukum bagi konsumen menurut UU Perlindungan Konsumen. Kedua Untuk mengetahui dan memahami bagaimana efektivitas persyaratan hygiene dan sanitasi

vol. 4 no. 2 Edisi September 2013, http://lppm3. bsi.ac.id/jurnal/index.php/khasanah_ilmu/ article/viewFile/143/76, diakses tanggal 22 september 2016, diakses tanggal 22 september 2016.

6 Ekawaty Prasetya, Hygiene dan Fasilitas Sanitasi Rumah Makan di Wilayah Kota Gorontalo, Jurnal Sainstek, Vol. 6 No. 5 Juli 2012,http://download.portalgaruda.org/ article.php? article $=13750 \& v a l=3591$, diakses pada 23 september 2016

7 M Iqbal Hasan, 2002, Pokok-Pokok Materi Metode Penelitian dan Aplikasinya, Cet. I, Ghalia Indonesia, Jakarta, hlm. 43. 
terhadap usaha rumah makan atau restoran sesuai dengan Kepmenkes RI Nomor 1098/Menkes/SK/VII/2003 di kawasan Ubud.

\section{METODE PENELITIAN}

a. Jenis penelitian

Jenis penelitian yang digunakan adalah penelitian hukum empiris, yaitu penelitian hukum yang dilakukan di lapangan dengan meneliti permasalahan penelitian dalam prakteknya di masyarakat. Hal tersebut dilakukan mengingat permasalahan yang diteliti menyangkut hubungan antara faktor sosial dan faktor yuridis. ${ }^{8}$ Sehingga penelitian ini disamping mengacu pada ketentuan Undang-Undang, teori, dan asas-asas hukum, juga harus dilakukan secara langsung ke lapangan terhadap pelakupelaku usaha yang bergerak dibidang usaha makanan dan restoran. Penelitian hukum empiris menurut sifatnya dapat dibedakan menjadi 3 (tiga), yaitu penelitian yang sifatnya eksploratif (penjajakan atau penjelajahan); penelitian yang sifatnya deskriptif dan penelitian yang sifatnya ekspalanatoris. Penulisan ini mempergunakan sifat penelitian deskriptif.

b. Data dan Sumber Data Data yang diteliti dalam

8 Ronny Hanitijo Soemitro, 1983, Metode Penelitian Hukum, Cet. I, Ghalia Indonesia, Jakarta, hlm. 141. penelitian ini adalah data primer dan data sekunder. Data adalah keterangan atau petunjuk tentang fakta, tanpa adanya fakta tidak akan ada data. Baik fakta ataupun data, peristiwa atau gejala, kesemuanya itu merupakan objek penelitian dalam penelitian ilmu-ilmu sosial dan ilmu hukum, begitu pula penelitian ini.

Data sekunder yang diper gunakan yakni Undang-Undang Dasar Republik Indonesia Tahun 1945, Undang-Undang Nomor 18 Tahun 2012 tentang Pangan, Undang-Undang Nomor 8 Tahun 1999 tentang Perlindungan Konsumen, Kepmenkes RI Nomor 1098 / Menkes / SK / VII / 2003 tentang Hygiene dan Sanitasi Usaha Rumah Makan dan Restoran. Literatur hukum sekunder seperti buku, jurnal, artikel-artikel hukum yang mempunyai relevansi dengan masalah yang diteliti. ${ }^{9}$ Literatur hukum tertier berupa internet.

Teknik pengumpulan data yang dikenal yaitu studi dokumen atau kepustakaan, pengamatan (observasi), wawancara (interview) dan daftar pertanyaan (kuesioner). Data primer didapatkan melalui wawancara. Teknik pengumpulan data yang sebaiknya digunakan tergantung pada ruang

Peter Mahmud Marzuki, 2010, Penelitian Hukum, Kencana Jakarta, hlm. 155. 
lingkup dan tujuan penelitian hukum yang dilakukan, yaitu khususnya mengenai tipe data yang akan diteliti. Meskipun demikian tipe data mana pun yang ingin diperoleh, selalu terlebih dahulu harus dilakukan studi kepustakaan atau studi dokumen.

Data diolah secara kualitatif dengan cara mengumpulkan data yang ada dalam kenyataannya dengan menonjolkan permasalahan yang ada dan dilengkapi dengan hasil wawancara sehingga memperoleh kesimpulan secara sistematis dari data tersebut. Analisa data disajikan secara deskriptif analitis yaitu menguraikan, menjelaskan, serta menggambarkan data yang didapatkan dan disajikan dengan pembahasan seperlunya. ${ }^{10}$

\section{HASIL DAN PEMBAHASAN}

\subsection{Kewajiban Pelaku Usaha}

Rumah Makan dan Restoran danPerlindungan Hukum Bagi Konsumen Menurut UndangUndang Nomor 8 Tahun 1999 tentang Perlindungan

\section{Konsumen}

Istilah konsumen berasal dari bahasa Inggris yaitu consumer yang artinya setiap orang yang menggunakan barang atau jasa dalam hal ini orang yang membeli suatu produk hanya

$\overline{10}$ Ronny Hanitijo Soemitro, 1988, Metodologi Penelitian Hukum dan Jurimetri, Ghalia Indonesia, Semarang, hlm. $51-52$. untuk digunakan oleh sendiri (pemakai akhir), bukan untuk dijual kembali. Karena posisi konsumen yang lemah maka perlu dilindungi oleh hukum, karena salah satu sifat sekaligus tujuan hukum adalah memberikan perlindungan kepada masyarakat.

Masalah perlindungan konsumen di Indonesia baru mulai terjadi pada dekade 1970-an. Hal ini ditandai dengan berdirinya Yayasan Lembaga Konsumen Indonesia (YLKI).Gagasan perlindungan konsumen disampaikan secara luas kepada masyarakat melalui berbagai kegiatan advokasi konsumen seperti pendidikan, penelitian, pengujian, pengaduan, publikasi media konsumen. ${ }^{11}$ Pasal 1 UndangUndang Nomor 8 Tahun 1999 tentang Perlindungan Konsumen (Selanjutnya UU Perlindungan Konsumen). Perlindungan konsumen adalah segala upaya yang menjamin adanya kepastian hukum untuk memberi perlindungan kepada konsumen.

Perlindungan konsumen identik dengan perlindungan hukum mengenai hak dan kewajiban konsumen maupun pelaku usaha, hak konsumen sebagaimana yang tertuang dalam Pasal 4 UU Perlindungan Konsumen, Hak konsumen yaitu:

a) Hak atas kenyamanan, keamanan, dan keselamatan dalam mengkonsumsi barang dan / atau jasa;

b) Hak untuk memilih barang dan/ atau jasa serta mendapatkan

11 Celina Tri Siwi Kristiyanti, 2008, Hukum Perlindungan Konsumen, Sinar Grafika, Jakarta, hlm.16. 
barang dan/atau jasa tersebut sesuai dengan nilai tukar dan kondisi serta jaminan yang dijanjikan;

c) Hak atas informasi yang benar, jelas dan jujur mengenai kondisi dan jaminan barang dan/atau jasa;

d) Hak untuk didengar pendapat dan keluhannya atas barang dan/ atau jasa yang digunakan;

e) Hak untuk mendapatkan advokasi, perlindungan dan upaya penyelesaian sengketa perlindungan konsumen secara patut;

f) Hak untuk mendapatkan pembinaan dan pendidikan konsumen;

g) Hak untuk diperlakukan atau dilayani secara benar dan jujur serta tidak diskriminatif;

h) Hak untuk mendapatkan kompensasi, ganti rugi dan atau penggantian, apabila barang dan/atau jasa yang diterima tidak sesuai dengan perjanjian atau tidak sebagaimana mestinya;

i) Hak-hak yang diatur dalam ketentuan peraturan perundangundangan lainnya"

Adapun mengenai kewajiban konsumen dijelaskan dalam Pasal 5 UU Perlindungan Konsumen, Kewajiban konsumen yaitu:

a) Membaca atau mengikuti petunjuk informasi dan prosedur pemakaian atau pemanfaatan barang dan atau jasa, demi keamanan dan keselamatan; b) Beritikad baik dalam melakukan transaksi pembelian barang dan / atau jasa;

c) Membayar sesuai dengan nilai tukar yang disepakati;

d) Mengikuti upaya penyelesaian hukum sengketa perlindungan konsumen secara patut."

Kajian terhadap perlindungan konsumen tidak dapat dipisahkan dari hak-hak dan kewajiban pelaku usaha, Pasal 6 UU Perlindungan Konsumen, Hak pelaku usaha yaitu:

a) Hak untuk menerima pembayaran yang sesuai dengan kesepakatan mengenai kondisi dan nilai tukar barang dan/atau jasa yang diperdagangkan;

b) Hak untuk mendapat perlindungan hukum dari tindakan konsumen yang beritikad tidak baik;

c) Hak untuk melakukan pembelaan diri sepatutnya di dalam penyelesaian hukum sengketa konsumen;

d) Hak untuk rehabilitasi nama baik apabila terbukti secara hukum bahwa kerugian konsumen tidak diakibatkan oleh barang dan/atau jasa yang diperdagangkan;

e) Hak-hak yang diatur dalam ketentuan peraturan perundangundangan lainnya."

Pelakuusahatidakdiperkenankan menambahkan bahan tambahan kedalam makanan yang dilarang oleh undang-undang serta penggunaannya melebihi batas atau standar yang 
ditentukan hal ini sejalan dengan ketentuan yang diatur dalam Pasal 7 UU Perlindungan Konsumen, yang menegaskan mengenai Kewajiban pelaku usaha adalah :

a) Beritikad baik dalam melakukan kegiatan usahanya;

b) Memberikan informasi yang benar, jelas dan jujur mengenai kondisi dan jaminan barang dan/atau jasa serta memberi penjelasan penggunaan, perbaikan dan pemeliharaan;

c) Memperlakukan atau melayani konsumen secara benar dan jujur serta tidak diskriminatif;

d) Menjamin mutu barang dan/atau jasa yang diproduksi dan/atau diperdagangkan berdasarkan ketentuan standar mutu barang dan/atau jasa yang berlaku;

e) Memberi kesempatan kepada konsumen untuk menguji, dan/ atau mencoba barang dan/atau jasa tertentu serta memberi jaminan dan/atau garansi atas barang yang dibuat dan/atau yang diperdagangkan;

f) Memberi kompensasi, ganti rugi dan/atau penggantian atau kerugian akibat penggunaan, pemakaian dan pemanfaatan barang dan/atau jasa yang diperdagangkan;

g) Memberi kompensasi, ganti rugi dan/atau penggantian apabila barang dan/atau jasa yang diterima atau dimanfaatkan tidak sesuai dengan perjanjian."
Perlindungan hukum yang dapat ditempuh pemerintah yaitu upaya preventif (pencegahan) dan represif (penanggulangan) baik bagi konsumen maupun pelaku usaha. ${ }^{12}$ Upaya perlindungan hukum secara preventif bagi konsumen adalah dengan melakukan sosialisasi berkala sebelum memutuskan untuk membeli makanan yang tidak memenuhi persyaratan hygiene dan sanitasi dan memiliki sertifikat laik hygiene dan sanitasi. Upaya represif yang dilakukan pemerintah untuk konsumen jika terjadi kasus keracunan makanan yaitu dengan memberikan pengobatan secara gratis sampai keadaannya sehat kembali. Sedangkan upaya preventif yang dilakukan pemerintah untuk pelaku usaha agar mencegah terjadinya kasus keracunan makanan yaitu dengan langkah sosialisasi mengenai pentingnya hygiene dan sanitasi pada makanan ke pelaku-pelaku usaha rumah makan dan restoran. Selain itu pemerintah juga dapat mendirikan suatu food court yang diberikan pada pelaku usaha dengan biaya sewa yang terjangkau. Pelaku usaha yang ingin membuka usaha di food court tersebut, tentunya sudah harus dibekali hygiene dan sanitasi terhadap makanan oleh pemerintah serta memiliki sertifikat laik hygiene dan sanitasi. Dengan pendirian food court ini selain menjaga keindahan tatanan kota dari usaha rumah makan dan restoran yang tidak

\footnotetext{
Philipus M. Hadjon, 1987, Perlindungan Hukum bagi Rakyat Indonesia, Bina Ilmu, Surabaya, hlm. 205.
} 
memenuhi persyaratan hygiene dan sanitasi, disini juga pemerintah dapat melakukan kontrol secara berkala dan lebih mudah. Upaya represif yang dilakukan pemerintah jika terjadi kasus keracunan makanan yang disebabkan oleh pelaku usaha tersebut karena tidak memiliki ijin hygiene dan sanitasi makanan adalah dengan memberikan teguran secara lisan, selanjutnya teguran tertulis. Apabila terjadi kasus keracunan makanan sampai menyebabkan korbannya meninggal maka penggugat dapat menempuh jalur hukum dan pemerintah kabupaten/kota mencabut sertifikat Laik Hygiene dan Sanitasi Makanan.

\subsection{Efektivitas Persyaratan Hygiene Sanitasi Terhadap Usaha Rumah Makan atau Restoran Sesuai Dengan Kepmenkes RI Nomor 1098/ Menkes/SK/VII/2003}

Pasal 1 angka 1 UndangUndang Nomor 18 Tahun 2012 tentang Pangan (selanjutnya disingkat UU Pangan) menyatakan pangan adalah segala sesuatu yang berasal dari sumber hayati produk pertanian, perkebunan, kehutanan, perikanan, peternakan, perairan dan air, baik yang diolah maupun tidak diolah yang diperuntukkan sebagai makanan atau minuman bagi konsumsi manusia, termasuk bahan konsumsi manusia, termasuk bahan tambahan pangan, bahan baku pangan, dan bahan lainnya yang digunakan dalam proses penyiapan, pengolahan, dan atau pembuatan makanan atau minuman.

Pasal 70 UU Pangan menyatakan sanitasi pangan dilakukan agar pangan aman untuk dikonsumsi. Setiap orang yang melakukan kegiatan atau proses produksi,penyimpanan, pengangkutan, dan atau peredaran pangan wajib memenuhi persyaratan sanitasi dan menjamin keamanan pangan dan atau keselamatan manusia.

Bagi penyelenggaraan makanan baik bersifat komersial maupun non komersial, menjaga keamanan makanan merupakan keharusan karena dapat membahayakan kesehatan orang banyak. Penyelenggara makanan harus yakin bahwa setiap makanan yang disajikan sudah benar-benar terbebas dari unsur-unsur yang dapat mengganggu kesehatan konsumennya.

Keamanan pangan menurut Pasal 1 angka 5 UU Pangan, Keamanan Pangan adalah kondisi dan upaya yang diperlukan untuk mencegah pangan dari kemungkinan cemaran biologis, kimia, dan benda lain yang dapat mengganggu, merugikan, dan membahayakan kesehatan manusia serta tidak bertentangan dengan agama, keyakinan, dan budaya masyarakat sehingga aman untuk dikonsumsi Pangan yang tidak aman dapat menyebabkan timbulnya berbagai penyakit.

Makanan bermutu atau berkualitas adalah makanan yang dipilih, dipersiapkan, dan disajikan dengan cara sedemikian sehingga tetap terjaga dan meningkat serta rasa, maupun nilai gizi dan menarik, dapat 
diterima serta aman dikonsumsi secara mikrobiologi dan kimiawi. PP Nomor 28Tahun2004 tentang Keamanan Mutu dan Gizi Pangan, dalam Pasal 1 angka 21 menyatakan bahwa mutu pangan adalah nilai yang ditentukan atas dasar kriteria keamanan pangan, kandungan gizi dan standar perdagangan terhadap bahan makanan dan minuman. Kelayakan pangan adalah kondisi pangan yang tidak mengalami kerusakan, kebusukan, menjijikkan, kotor, tercemar atau terurai. Keamanan pangan adalah kondisi dan upaya yang diperlukan untuk mencegah pangan dari kemungkinan cemaran biologis, kimia dan benda lain yang dapat mengganggu, merugikan dan membahayakan kesehatan manusia.

Untuk mengidentifikasi dan mengendalikan bahaya yang bisa berdampak pada keamanan pangan diperlukan 'Jaminan Mutu' terhadap makanan yang dihasilkan. Sebagaimana ditetapkan dalam UU Pangan maka penerapan standar mutu untuk produk pangan dan mutu di dalam proses produksi telah menjadi suatu kewajiban (mandatori) yang harus dijalankan oleh para produsen pangan. Dalam UU Pangan, Keamanan Pangan secara tegas telah diatur bahwa produsen produk pangan harus mampu untuk memenuhi berbagai persyaratan produksi sehingga dapat memberikan jaminan dihasilkannya produk pangan yang aman dan bermutu bagi konsumen. Jaminan mutu bukan hanya menyangkut masalah metode tetapi juga merupakan sikap tindakan pencegahan terjadinya kesalahan dengan cara bertindak tepat sedini mungkin oleh setiap orang baik yang berada di dalam maupun di luar bidang produksi.

Sanitasi makanan merupakan salah satu upaya pencegahan yang menitikberatkan pada kegiatan dan tindakan yang perlu untuk membebaskan makanan dan minuman dari segala bahaya yang dapat mengganggu atau merusak kesehatan mulai dari sebelum makanan diproduksi, selama proses pengolahan, penyiapan, pengangkutan, penjualan sampai pada saat makanan dan minuman tersebut siap untuk dikonsumsi kepada konsumen. Salah satu kegiatan dari sanitasi makanan adalah penyehatan makanan dan minuman. Pelaksanaan sanitasi makanan dalam penyelenggaraan makanan meliputi :

1. Ruang Pengolahan (Dapur)

2. Bangunan

3. Sarana dan peralatan untuk pelaksanaan sanitasi makanan

4. Air bersih

Hygiene adalah upaya kesehatan dengan cara memelihara dan melindungi kebersihan lingkungan dari subyeknya seperti mencuci tangan dengan air bersih dan sabun untuk kebersihan tangan, mencuci piring untuk melindungi kebersihan piring. Membuang bagian makanan yang rusak 
untuk melindungi keutuhan makanan secara keseluruhan dan sebagainya.

Hygiene dan sanitasi makanan harus dimiliki oleh pelaku usaha rumah makan maupun restoran. Pasal 1 angka 4 Kepmenkes RI Nomor 1098/ Menkes/SK/VII/2003 Hygiene dan sanitasi makanan adalah upaya untuk mengendalikan faktor makanan, orang, tempat dan perlengkapan yang dapat atau mungkin dapat menimbulkan gangguan kesehatan. Pengertian rumah makan juga disebutkan didalam Pasal 1 angka 1 Kepmenkes RI Nomor 1098/ Menkes/SK/VII/2003.Rumah makan adalah setiap tempat usaha komersil yang ruang lingkup kegiatannya menyediakan makanan dan minuman untuk umum di tempat usahanya. Sedangkan restoran adalah salah satu jenis usaha jasa pangan yang bertempat di sebagian atau seluruh bangunan yang permanen dilengkapi dengan peralatan dan perlengkapan untuk proses pembuatan, penyimpanan, penyajian dan penjualan makanan dan minuman bagi umum ditempat usahanya.

Rumah makan dan restoran dalam menjalankan usahanya harus memenuhi persyaratan hygiene dan sanitasi meliputi :

1. Persyaratan lokasi dan bangunan,

2. Persyaratan fasilitas sanitasi,

3. Persyaratan dapur, ruang makan dan gudang makanan,

4. Persyaratan bahan makanan dan makanan jadi,
5. Persyaratan

pengolahan

makanan,

6. Persyaratan penyimpanan bahan makanan dan makanan jadi;

7. Persyaratan penyajian makanan jadi,

8. Persyaratan peralatan yang digunakan.

Setiap rumah makan dan restoran harus memiliki izin usaha dari pemerintah. Untuk memiliki izin usaha tersebut rumah makan dan restoran harus memiliki sertifikat layak hygiene sanitasi rumah makanan dan restoran yang dikeluarkan oleh Dinas Kesehatan Kabupaten/ Kota.

Usaha di bidang makanan dan restoran merupakan bidang usaha yang menguntungkan bagi pengusahanya. Bertolak daripemikiran yang sederhana yaitu makanan adalah kebutuhan primer bagi setiap orang. Maraknya usaha di bidang makanan bisa dilihat usaha tersebut kurang memperhatikan persyaratan hygiene dan sanitasi makanan. Banyak usaha makanan yang dalam bentuk rumah makan dan di pinggir jalan. Usaha rumah makan tersebut dibuat dalam bentuk tenda dan sudah dipastikan tidak memenuhi persyaratan dari hygiene dan sanitasi makanan tersebut. Berdasarkan hasil wawancara ke beberapa pemilik rumah makan di kawasan ubud, Pelaku usaha rumah makan khususnya kurang mengetahui apayang dimaksudhygiene dan sanitasi makanan. Tetapi, usaha rumah makan yang dipinggir jalan tersebut, menjadi daya tarik tersendiri 
bagi konsumen atau wisatawan baik wisatawan domestik maupun mancanegara maupun masyaraka setempat karena dilihat dari segi rasa dan harga, harganya sangat terjangkau bagi semua kalangan.

Kurangnya perhatian pelaku usaha rumah makan dan restoran terhadap syarat hygiene dan sanitasi, dapat menyebabkan terjadinya kasus keracunan makanan. Seperti yang disebutkan dalam latar belakang dua turis Australia yang di duga meninggal akibat keracunan makanan. Kasus posisi mengenai dua turis Australia Noelene Gaye Bischoff (54) dan anak perempuannya, Yvana Jeana Yuri Bischoff (14) sebelum berlibur dan menginap di Padang Bai Karangasem, mereka makan di restoran kawasan Ubud dan memesan menu seafood. Keduanya ditemukan meninggal dunia saat berlibur di Padang Bai. Namun untuk memastikan kematian korban warga asing itu, kepolisian Bali saat ini sedang meneliti sampel muntahan korban di laboratorium forensik Denpasar. Selain itu, manager dan pegawai Warung Dewa Malen juga telah diperiksa sebagai saksi. Dalam hal terjadinya kasus keracunan makanan pada konsumen, tentu pemerintah harus ikut melindungi pelaku usahanya selain melindungi konsumennya.

Untuk menjawab permasalahan efektivitas persyaratan hygiene sanitasi terhadap usaha rumah makan atau restoran sesuai dengan Kepmenkes RI Nomor 1098/Menkes/SK/VII/2003, menggunakan Teori Sistem Hukum dari Lawrence Friedman. Lawrence M. Friedman mengungkapkan Three Elements of Legal System atau tiga komponen dari system hukum. Ketiga komponen yang dimaksud yaitu: ${ }^{13}$

(1) Struktur (structure),

(2) Substansi (substance), dan

(3) Kultur (culture) atau budaya

Substansi mencakup isi normanorma hukum beserta perumusannya maupun cara menegakkannya, yang berlaku bagi pelaksana hukum maupun pencari keadilan. Substansi juga mencakup hukum yang hidup di tengah masyarakat bukan hanya pada aturan-aturan yang ada di dalam bukubuku hukum/UU/ putusan hakim. Struktural mencakup wadah maupun bentuk dari system tatanan lembagalembaga formal, hubungan atar lembaga-lembaga tersebut, hak-hak dan kewajibannya. Kultural mencakup nilai-nilai dalam masyarakat yang mendasari hukum yang berlaku. Teori sistem ini menitikberatkan kepada 3 (tiga) sistem yaitu : struktur, substansi, dan budaya. Dilihat dari segi struktur, sudah ada wadah atau bentuk dari sistem tatanan lembaga-lembaga formal. Ditinjau dari substansi, peraturan perundang-undangan serta keputusan-keputusan dari Menteri sudah mengatur mengenai hygiene dan sanitasi makanan. Ditinjau dari segi budaya, yang masih lemah,

13 Lawrence M. Friendman, 2009, Sistem Hukum Perspektif Ilmu Sosial (The Legal System : A Social Science Perspektive), (M. Khozim, Pentj), Nusa Media, Bandung, hlm.12-18. 
karena kurang adanya kesadaran dari pelaku makanan tersebut untuk mengutamakan kesehatan makanan. Sebagaimana diketahui bahwa makanan adalah sumber penyebaran penyakit yang utama.

Efektivitas persyaratan hygiene dan sanitasi terhadap terhadap usaha rumah makan atau restoran sesuai dengan Kepmenkes RI nomor 1098/ Menkes/SK/VII/2003 belum bisa terlaksana dengan baik, (berdasarkan hasilwawancara pada hari senin 27 Juni 2016 dengan Nyoman Sukarena pande selaku Fungsional Sanitasi di Dinas Kesehatan Kabupaten Gianyar) beliau mengatakan bahwa masih banyak pelaku usaha rumah makan khususnya kurang memperhatikan hygiene dan sanitasi terhadap makanan.

Pelaku usaha restoran umumnya sudah memiliki sertifikat laik hygiene dan sanitasi makanan, sebab hygiene dan sanitasi merupakan persyaratan dalam memperoleh ijin restoran. Petugas dinas kesehatan selalu melakukan evaluasi dan pengontrolan setiap 6 (enam) bulan sekali baik ke rumah makan yang tidak memiliki sertifikat laik hygiene dan sanitasi dan ke restoran yang dilakukan oleh tenaga sanitariandan timmedis daripuskesmas setempat. Secara tidak langsung restoran maupun rumah makan selalu diawasi oleh tim sanitarian dari Dinas Kesehatan. Kegiatan ini dilakukan sebagai upaya preventif

Tim sanitarian dari Dinas Kesehatan juga menyosialisasikan mengenai pentingnya hygiene dan sanitasi makanan kepada pelaku usaha yang bergerak di bidang usaha makanan. Upaya preventif lainnya yang dilakukan oleh pemerintah dapat berupa; pembinaan dan penyuluhan dari pemerintah terhadap produsen maupun pedagang makanan mengenai pentingnya hygiene dan sanitasi makanan, melakukan pengawasan baik secara langsung maupun tidak langsung terhadap produsen dan pedagang makanan, serta mempermudah akses para pelaku usaha untuk memperoleh sertifikat hygiene sanitasi makanan. Upaya represif yang dilakukan oleh pemerintah adalah sesuai dengan ketentuan Pasal 13 Kepmenkes RI Nomor 1098/Menkes/SK/VII/2003 yaitu pemberian sanksi terhadap rumah makan atau restoran yang melakukan pelanggaran. Sanksi yang diberikan yaitu sanksi administratif, sanksi ini berupa teguran lisan, teguran tertulis, dan pencabutan sertifikat laik hygiene sanitasi rumah makan dan restoran.

Selain itu perlunya kebijakan dari pemerintah daerah untuk mengatasi mengenai pengusaha makanan atau restoran yang tidak memenuhi hygiene sanitasi. Model perumusan kebijakan publik yang bisa digunakan adalah model sistem. ${ }^{14}$ Model ini mengasumsikan bahwa dalam pembentukan kebijakan terjadi interaksi yang terbuka dan dinamis

\footnotetext{
14 Budi Winarno, 2011, Kebijakan Publik : Teori, Proses dan Studi Kasus (Edisi dan Revisi Terbaru), CAPS, Yogyakarta, hlm. 97-98.
} 
antara para pembentuk kebijakan dengan lingkungannya. Menurut model sistem, kebijakan publik dipandang sebagai tanggapan dari suatu sistem politik terhadap tuntutan-tuntutan yang timbul dari lingkungan yang merupakan kondisi atau keadaan yang berada di luar batas-batas sistem politik. Kekuatan-kekuatan yang timbul dari dalam lingkungan dan mempengaruhi sistem politik dipandang sebagai masukan-masukan (inputs) bagi sistem politik, sedangkan hasil-hasil yang dikeluarkan oleh sistem politik yang merupakan tanggapan terhadap tuntutan - tuntutan di pandang sebagai keluaran (outputs).

Dikaitkan dengan penanggulangan maraknya usaha makanan dan restoran yang tidak memperhatikan hygiene dan sanitasi, maka pemerintah dalam melakukan perumusan kebijakannya tidak boleh melakukan perumusan sepihak dari pemerintah saja, tetapi harus mengikutsertakan perwakilan dari beberapa pengusaha di bidang makanan dan restoran, untuk ikut serta memberikan masukan-masukan (inputs) terhadap kebijakan yang akan dirumuskan tersebut. Sehingga akan terciptanya kebijakan dari pemerintah dari bentuk regulasi mengenai hygiene dan sanitasi usaha makanan dan restoran dalam bentuk perda provinsi, sehingga dapat berlaku efektif.

\section{KESIMPULAN}

1. Efektivitas persyaratan hygiene sanitasi terhadap usaha rumah makan atau restoran sesuai dengan Kepmenkes RI Nomor 1098/Menkes/SK/VII/2003, belum terlaksana dengan maksimal. Dilihat dari maraknya usaha rumah makan dan restoran yang dibangun secara bebas tanpa memperhatikan jarak dari satu tempat rumah makan ke tempat rumah makan yang lainnya. Pembangunan rumah makan ini juga tidak memperhatikan keindahan kota. Selain itu hampir tidak semua rumah makan dan restoran memiliki sertifikat laik hygiene dan sanitasi. Dan bahkan ad a beberapa yang tidak mengetahui apa yang dimaksud hygiene dan sanitasi makanan.

2. Upaya perlindungan hukum secara preventif bagi konsumen adalah dengan melakukan sosialisasi kepada konsumen mengenai pentingnya hygiene dan sanitasi bagi usaha makanan atau restoran. Upaya represif yang dilakukan pemerintah untuk konsumen jika terjadi kasus keracunan makanan yaitu dengan memberikan pengobatan secara gratis bagi konsumen ampai ia sehat. Sedangkan upaya preventif yang dilakukan pemerintah untuk pelaku usaha agar mencegah terjadinya kasus keracunan makanan yaitu dengan 
langkah sosialisasi mengenai pentingnya hygiene dan sanitasi pada makanan ke pelakupelaku usaha rumah makan dan restoran. Selain itu pemerintah juga dapat mendirikan suatu food court yang diberikan pada pelaku usaha dengan biaya sewa yang murah. Pelaku usaha yang ingin membuka usaha di food court tersebut, tentunya sudah harus dibekali hygiene dan sanitasi terhadap makanan oleh pemerintah serta memiliki sertifikat laik hygiene dan sanitasi. Dengan pendirian food court ini selain menjaga keindahan tatanan kota dari rumah makan dan restoran yang tidak memenuhi persyaratan hygiene dan sanitasi, disini juga pemerintah dapat melakukan kontrol secara berkala dan lebih mudah. Upaya represif yang dilakukan pemerintah jika terjadi kasus keracunan makanan yang disebabkan oleh pelaku usaha tersebut karena tidak memiliki ijin hygiene dan sanitasi makanan adalah dengan memberikan teguran secara lisan, selanjutnya teguran tertulis. Apabila terjadi kasus keracunan makanan sampai menyebabkan korbannya meninggal maka penggugat dapat menempuh jalur hukum pidana.

\section{DAFTAR PUSTAKA}

Budi Winarno, 2011, Kebijakan Publik: Teori, Proses dan Studi Kasus (Edisi dan Revisi Terbaru), CAPS, Yogyakarta.

Celina Tri Siwi Kristiyanti, 2008, Hukum Perlindungan Konsumen, Sinar Grafika, Jakarta.

I Gde Pitana \& I Ketut Surya

Diarta, 2009, Pengantar Ilmu

Pariwisata, CV Andi Offset, Yogyakarta.

Lawrence M. Friendman, 2009, Sistem Hukum Perspektif Ilmu Sosial (The Legal System : A Social Science Perspektive), (M. Khozim, Pentj), Nusa Media, Bandung.

M Iqbal Hasan, 2002, Pokok-Pokok

Materi Metode Penelitian dan

Aplikasinya, Cet. I, Ghalia Indonesia, Jakarta.

Peter Mahmud Marzuki, 2010, Penelitian Hukum, Kencana Jakarta.

Philipus M. Hadjon, 1987,

Perlindungan Hukum bagi

Rakyat Indonesia, Bina Ilmu, Surabaya.

Ronny Hanitijo Soemitro, 1983, Metode Penelitian Hukum, Cet.

I, Ghalia Indonesia, Jakarta.

Ronny Hanitijo Soemitro, 1988, Metodologi Penelitian Hukum dan Jurimetri, Ghalia Indonesia, Semarang.

Zainuddin, Ali.2009. Metode Penelitian Hukum, Sinar Grafika Jakarta. 


\section{Jurnal}

Yuni Yuliastri dan Atun Yulianto, Peranan Hygiene dan Sanitasi Untuk Menjaga Kualitas Makanan dan Kepuasan Tamu di Hotel Inna Garuda Yogyakarta, Jurnal Khasanah Ilmu, vol. 4 no.2 Edisi September 2013, http://lppm3.bsi.ac.id/jurnal/ index.php/khasanah_ilmu/ article/viewFile/143/76, diakses tanggal 22 september 2016.

Ekawaty Prasetya, Hygiene dan Fasilitas Sanitasi Rumah Makan di Wilayah Kota Gorontalo, Jurnal Sainstek, Vol. 6 No. 5 Juli 2012, http://download. portalgaruda.org/article. php? article $=137505 \& \mathrm{val}=3591$, diakses pada 23 september 2016. 